УДК ???

\title{
ИСПОЛЬЗОВАНИЕ ИЗЛУЧЕНИЙ ГЛОБАЛЬНЫХ НАВИГАЦИОННЫХ СПУТНИКОВЫХ СИСТЕМ ДЛЯ РЕШЕНИЯ ЗАДАЧ РАДИОЛОКАЦИИ*
}

\author{
ЛАУШ А. Г. ${ }^{1}$, ЛУЦЕНКО В. И. ${ }^{2}$, ЛУЦЕНКО И. В. ${ }^{2}$ \\ ${ }^{1}$ ООО «Навис-Украина», \\ Украина, Смела, 20708, ул. Мазура 24 \\ ${ }^{2}$ Институт радиофизики и электроники Национальной Академии наук Украины, \\ Украина, Харьков, 61085, ул. Проскуры 12
}

\begin{abstract}
Аннотация. Рассмотрена возможность использования излучений глобальных навигационных спутниковых систем для обнаружения воздушных объектов. Получены соотношения для оценки дальности обнаружения. Определены требования к степени подавления прямого сигнала подсветки. Сформулированы требования к приемным системам, расположенным на низкоорбитальных ИСЗ для решения задач глобальной радиолокации. Определены дальности обнаружения объектов при использовании подсветки упрощенными сигналами наземных псевдоспутников и предложен вариант построения бистатической системы локации
\end{abstract}

Ключевые слова: навигационная спутниковая система; ГНСС; ИСЗ; радиолокация; РЛС; ГЛОНАСС; GPS; эффективная поверхность рассеяния; ЭПР

\section{1. ВВЕДЕНИЕ}

Первые идеи использования активно-пассивной радиолокации относятся к 50-м годам прошлого века. В последнее время появились попытки перехода от идей к практической реализации. Это объясняется большей живучестью этих РЛС и скрытностью работы.

За это время создана теория построения активно-пассивных РЛС, проведены их испытания и внедрены многие важные компоненты многопозиционных радаров $[1,2]$. Намечены пути создания активно-пассивных систем, использующих излучения существующих вещательных станций [3] или телевизионных цен- тров и систем мобильной связи для «подсветки» обстановки $[4,5]$.

Аспекты построения пространственно-когерентных бистатических радиолокаторов, применяющих для подсветки зоны обнаружения излучений воздушных целей квазишумоподобные сигналы, рассмотрены в $[1,2,5]$. В них проведен анализ возможных вариантов построения пассивного канала бистатических радиолокационных комплексов: угломерно-угломерного (триангуляционного) и угломерно-разностно-дальномерного (гиперболического). Эти принципы построения многопози-

* Работа со стороны компании «ООО Навис-Украина» проведена инициативно, а со стороны ИРЭ НАНУ при финансовой поддержке в рамках Целевой комплексной программы НАН Украины, по научным космическим исследованиям на 2012-2016 гг. 